\title{
Canada's contemporary policy on Aboriginal education
}

\author{
Larisa Garusova* \\ Far Eastern Federal University, FEFU Campus, 10 Ajax Bay, Russky Island, Vladivostok 690922, Russia \\ Institute of History, Archaeology and Ethnography of the Peoples of the Far East, IHAE FEB RAS, 89 Pushkinskaia St., Vladivostok \\ 690001, Russia
}

\begin{abstract}
The article analyzes the process of transformation of the educational system of the Indigenous peoples, the key factor of which is the policy of the Canadian government. Based on the analysis of documents and materials of the federal government of Canada and regional authorities, qantitative and qualitative characteristics of the modern educational status of Aboriginal peoples have been identified. Canada's Aboriginal education system has gone through a difficult path from destructive forms of education for culture, family and personality, to humane and careful attitude towards students, their national roots and traditions. The policy of compensating for the damage done in the past and supporting the Indigenous peoples in the field of education goes in several directions. Among them there are payments to those Aborigines who have suffered physically or mentally in boarding schools in the past; equalization of education levels of Indigenous peoples and other Canadians, support of Aboriginal languages and culture. The main tools in the implementation of modern government policy are increased funding for the education of the Indigenous population and the collaboration of the authorities with public organizations and Aboriginal communities.
\end{abstract}

\section{Introduction}

Canada is one of the largest Arctic states (40\% of its territory is considered Northern and Arctic) with a complex multi-ethnic and multicultural social structure, in which Aboriginal peoples occupy an important place. According to the latest (to date) 2016 census, more than 1.67 million people in Canada identify themselves as Indigenous peoples, which is $4.9 \%$ of the total population of the country. Only 260.5 thousand of these people (about 16\%) speak their native languages. There are 630 Indigenous communities in Canada, representing more than 50 nations and 50 Aboriginal languages [1]. The Aboriginal population consists of 3 groups: "First Nations" - Indians (meaning both status having, i.e. registered in the appropriate legal status by the "Indian Act", and non-status holders); Metis; Inuit. The history of the relationship between the Canadian government and the Native Canadians is complex and dramatic: the Aborigines were forcibly assimilated, their rights and resources were restricted, their culture and native languages were banned and destroyed. Currently, Canada's ethnic policy has changed radically. However, the experience of overcoming the negative consequences of the actions of the Canadian state, including the field of education, may be of interest and use for countries with multi-ethnic and multicultural populations.

The Northern and Arctic regions of Canada include Yukon, Northwest Territories, Nunavut, northern parts of the provinces of Manitoba, Newfoundland and Labrador, Quebec. The Arctic region is characterized by low population size and density, as well as a limited number of economic growth factors, which has formed several barriers to further regional development. Among them is the low level of education of the population, especially Aboriginal, which, in turn, is an obstacle to the diversification of the regional economy and the formation of its new industries.

\section{Results and Discussion}

The Indigenous population of Canada is relatively young - about $44 \%$ were under the age of 25 in 2016 . The average age of Inuit, for example, is only 24 years old [2]. Therefore, the problem of obtaining a full-fledged education is very relevant for Aboriginal youth. Statistical data, as well as research on this topic, indicate that Aboriginal groups living both on and off reservations have a lower level of education compared to other Canadians. According to the Government of Canada for 2018, about 44\% of Indigenous people on reservations (ages 18-24) have completed high school, compared to $88 \%$ of the other Canadians [3].

The Indigenous peoples are ahead of the rest of Canadians in terms of incomplete school education. And this situation is changing quite slowly. So, in 2017, there were $9 \%$ of Canadians aged 25-64 years who did not finish high school and did not receive another education, and among the Indigenous population (not living on reservations), this figure was $19 \%$, i.e. more than 2 times higher. In 2020, this indicator corresponded to $8 \%$ and $17 \%$. Over the past four years, the share of Aborigines whose education has been limited to high school has

\footnotetext{
Corresponding author: lgarusova@mail.ru
} 
remained stable - $29 \%$. For comparison, this indicator is gradually decreasing among the rest of the population (in $2017-24 \%$, in $2020-22 \%$ ) due to further education at colleges and universities [4].

Often, representatives of Aboriginal peoples are a year or two slower than other schoolchildren to master the curriculum, especially in high school. Thus, according to the heads of the British Columbia Department of Education, graduation rates among Indigenous students in the public school system are continuing to decline, in spite of a funding injection of nearly $\$ 13$ million for a unique learning strategy to support them in 2020. Only $46.9 \%$ of Indigenous students completed high school within four years, and only 50.1 graduated within five years, that significantly lower than the $64 \%$ provincial average for both data sets. In comparing Indigenous students to the overall population, $78.3 \%$ of all students finished high school in three years, and $82.9 \%$ graduated in four years [5].

An important problem of school education is a high absence rate among Aboriginal children. The level of school attendance among representatives of the Indigenous population and other schoolchildren differs drastically. For example, in Yukon schools in the academic years of 2019-2020, students who've missed 20 or more days for Yukon First Nations accounted for $36 \%$, and non-First Nations and Yukon-wide - 13\% [6, p. 25].

The origins of these and other problems in the education of the Indigenous peoples are largely rooted in the previous Canada's government policy. Canada's Aboriginal education system has undergone significant changes in recent decades. It has gone a long way from the educational methods that are destructive to culture, family and personality for children and youth, to humane and careful attitude towards students, their national roots and traditions. In the colonial era, the authorities set a course for the forced assimilation of the Canadian Aborigines with all the ensuing consequences for their culture. The colonial (and later federal) authorities saw Christianization and "Agrarianization" as important tools for assimilation of the Indigenous population. The introduction of a new education system by the Indian Act of 1876 continued the destructive changes in Aboriginal culture. The amendment of 1894 provided for compulsory schooling for all children. However, this important norm of European education turned out to be disastrous for the Aboriginal community. Most families were forced to send their children to study in specialized boarding schools (Indian residential schools) located far from home. Boarding schools did not provide decent living conditions, in addition, children there were often subjected to various kinds of violence. Deaths among the pupils were common. Besides teaching literacy and basic school subjects, the purpose of these boarding schools was assimilation, an important tool of it was a strict ban on the use of native languages by students. As a result, this led to the loss of a huge number of Aboriginal languages. In the learning process, not only languages were ignored, but also culture in general, the peculiarities of thinking and behavior of Indigenous people, which led to a deterioration in the physical and psychological state of a significant part of schoolchildren.

One of the key difficulties of Indian education was the training of teachers from among the Aborigines. Great difficulties arose in the financing of boarding schools: the federal government did not allocate enough funds to organize proper education. Often, the students themselves carried out household work for the maintenance of schools. At the same time, the task of adapting Aboriginal children to life in Canadian society with the European model has not been solved. Parents did not seek to send their children to boarding schools, dissatisfied with the fact that children forgot their native language and were subjected to harsh treatment. In addition, education did not meet the requirements of the Indians' daily life: returning to the communities, children were fast to forget everything they had been taught in schools and obeyed the customs of the tribe.

Unlike the rest of Canada, the Arctic region was later and on a smaller scale affected by the policy of aggressive assimilation of the Canadian state, although the model of Aboriginal education here turned out to be the same as everywhere else. From 1670 to 1870 , the Hudson's Bay Company (HBC) controlled large swaths of land in the North and West due to a royal charter granted by King Charles II. Interested solely in trade, HBC initially discouraged missionary activity on its land and had no desire to educate or assimilate the Indigenous population. After these lands, known as the NorthWestern Territory and Rupert's Land, were ceded to the newly formed Dominion of Canada in 1870, missionaries began to have a larger presence in the North and expanded on the few mission schools that had been opened in the 1860s. However, like the Hudson's Bay Company, the Canadian government had little interest in educating the Northern Indigenous population, as it was assumed that having a formal education was futile for people living in such isolated regions. The Canadian government also hoped that Indigenous peoples in the North would maintain their traditional lifestyles and thus not rely on the government for assistance. Frank Oliver, minister of the interior, granted the capital and operating costs for a new boarding school in the Yukon in 1909 but stated, "I will not undertake in a general way to educate the Indians of the Yukon. In my judgment they can, if left as Indians, earn a better living" [7, p. 24]. Due to the lack of government support and the meager funds available, the schools that were established were marked by inadequate facilities, unqualified teachers, a lack of supplies and curriculum, and they operated intermittently, closing and opening based on the availability of teachers and funds and on the migratory patterns of the Native population.

The radical changes that took place in Canadian society in the second half of the XX century forced the federal government to take radical measures to adapt Indian schools to new realities. The Government understood that the future of the whole of Canada would depend on how the fate of Indigenous peoples was resolved. A country whose population rejects the benefits of integration will inevitably find itself in a difficult situation. 
The real transformation of Aboriginal education across the country occurred in 1969 with the release of the "White Paper" and the subsequent Aboriginal response. The White Paper argued that in order for the conditions of Aboriginal peoples to be improved they needed to be made full and equal citizens in Canadian society. To achieve "full equality" the Indian Act was to be repealed, the Department of Indian Affairs eliminated, and all special legal statuses for Indians were to be removed. Aboriginal peoples were to become just one more element in a multicultural society. First Nations reacted swiftly to the proposed policy, condemning the paper as an attempt by the government to shirk its responsibility to First Nations and as a promotion of cultural genocide. One of the most significant of these position papers was the National Indian Brotherhood's 1972 paper titled Indian Control of Indian Education. The National Indian Brotherhood's paper was a comprehensive statement of the need for local control of Aboriginal education. The documents of the Indian Control of Indian Education proclaimed the goals and objectives of a new approach to the education of the Indigenous population of Canada: "As our fathers had a clear idea of what made a good man and a good life in their society, so we modern Indians, want our children to learn that happiness and satisfaction come from: pride in one's self, understanding one's fellowmen, and, living in harmony with nature. We want education to give our children the knowledge to understand and be proud of themselves and the knowledge to understand the world around them" [8]. The document pointed out two main means of achieving the set goals and at the same time formulated two fundamental principles of education in a democratic country: parental responsibility and local control.

The program Indian Control over Indian education is based on the participation of parents in the educational process, as well as on the direct control of representatives of the First Nations over the functioning of the educational system on the territory of reservations and Aboriginal settlements. The program has officially recognized parental representatives of Indigenous peoples having the same rights in making decisions about the education of their children like all other parents in Canada.

After accepting Indian Control of Indian Education as the National policy statement on Aboriginal education (1973), the government began to devolve some administrative control of schools to First Nations communities. Gradually, Indigenous peoples began to get involved in the educational process, demanding that their interests be taken into account, and the situation in schools began to change for the better. The rights given to Indigenous peoples in the educational sphere required the creation of a new multi-level system of control over education, which involves both federal and provincial authorities, along with local communities. Thus, in addition to the right to establish their own schools on the territory of reservations, Indigenous peoples have the right to have their representatives on school boards in provinces and territories outside reservations, where Aboriginal children also study.
Canadian society's awareness of the harmfulness of the previous educational policy and the need to compensate for the damage it caused to Aboriginals, as well as the cooperation of the federal government with organizations and local communities, led to the registration of the Indian Residential Schools Settlement Agreement (IRSSA), in May 2006. Under the terms of the agreement, former residential school students were provided monetary compensation in the form of a "common experience payment" along with additional compensation based on their years of attendance at a residential school. The agreement also established an Independent Assessment Process for former students to pursue claims of sexual and physical abuse, provided \$125 million for the Aboriginal Healing Foundation to continue their healing programs, granted additional funding to support local and national commemoration projects, and included provisions for the establishment of a five-year Truth and Reconciliation Commission. Furthermore, in June 2008 the federal government finally issued a formal apology for its role in the creation and operation of the residential school system [7, p. 28].

Despite the positive changes in modern Canadian politics, Indigenous peoples are not going to forget their traumatic experience of boarding schools. They continue to share it with other Canadians and use it as a means of moral support for the victims and a tool to improve the education system of Aborigines. Thus, according to employees of the Yukon Department of Education, the residual negative impact of boarding schools on the school education system and the consciousness of the Indigenous population has not been eliminated today. The official website of the Yukon Government's Department of Education states that many Yukon First Nations students and their families continue to be affected by the legacy of residential schools. Recognizing these effects helps us to: better meet the needs of these students; and - support them to succeed in their studies. Learning about the history and impact of residential schools is important for all Canadians [9].

The negative historical experience of Aborigines in the field of education continues to be a reason for legal proceedings and accusations against the authorities. So, in 2007 and 2008, 5 class-actions were filed against the Government of Canada in the Supreme Court of Newfoundland and Labrador. These lawsuits concerned 5 residential schools in Newfoundland and Labrador. Inuit, Innu and NunatuKavut individuals attended these schools and, as plaintiffs in these lawsuits, claimed sexual and physical abuse, neglect, language and cultural loss. The schools were administered by the Government of Newfoundland and operated by the International Grenfell Association and the Moravian Mission. Canada's role was to provide funding to the province to be used for the educational needs of Indigenous students in Labrador. The residential schools and the timelines covered by the claims period are: Lockwood School: April 1, 1949 to June 30, 1964 (Cartwright, Labrador); Makkovik Boarding School: April 1, 1949 to June 30, 1960 (Makkovik, Labrador); Nain Boarding School: April 1, 1949 to June 30, 1973 (Nain, Labrador); St. Anthony Orphanage and Boarding School: April 1, 1949 
to June 30, 1979 (St. Anthony, Newfoundland); Yale School: April 1, 1949 to June 30, 1980 (Northwest River, Labrador).

On September 28, 2016, upon conclusion of the Supreme Court of Newfoundland and Labrador approved the settlement agreement to all parties interested. Under the terms of the settlement, Canada provided a lump sum payment of $\$ 50$ million to plaintiffs as compensation for attendance at the residential schools, as well as for serious abuse claims. As part of the settlement agreement, Canada provided funds to the three Indigenous groups (Innu Nation, Nunatsiavut Government and NunatuKavut Community Council) to complete their own healing and commemoration initiatives. On November 24, 2017, Prime Minister Trudeau apologized to former students of Newfoundland and Labrador residential schools and their families in Happy Valley-Goose Bay. At the same time, the Prime Minister officially launched the healing and commemoration portion of the settlement agreement. This apology is an important step on the path to reconciliation between the Government of Canada and Indigenous peoples [10].

However, it is a matter of respect that the Government of Canada is not trying to hide the inhumane mistakes of its predecessors, but on the contrary, recognizes them and tries to compensate or mitigate the negative consequences of educational and assimilation official policies. Today, federal authorities, provincial and territorial governments, together with Indigenous communities and organizations, are trying to overcome the negative experience of the past and help Aborigines solve at least two tasks: first, to catch up with other Canadians in terms of education; secondly, to preserve and restore autochthonous cultures and languages that suffered loss, during the policy of aggressive assimilation.

In the first case, radical changes in recent years, unfortunately, have not happened, although there are already some positive developments. As noted above, only about $44 \%$ of First Nations on reserves (age 18-24) have completed high school, compared to $88 \%$ for other Canadians in 2018. However, almost the same level of education of Aborigines was revealed during studies among Inuit (2011-2012). It turned out that only $42 \%$ of Inuit between the ages of 18 and 44 received a high school graduation certificate. At the same time, girls and women were somewhat ahead in terms of numbers of male graduates ( $46 \%$ vs. $36 \%$ ). For comparison, $89 \%$ of the non-Aboriginal population aged 18 to 44 years managed to master the school education program. Among the reasons why Inuit men dropped out of school were school problems $(22 \%)$, lack of interest $(15 \%)$, desire to work $(11 \%)$. The main reason for the dropout of female graduates was pregnancy or the need to take care of their children - $38 \%$ [2].

Higher education in Canada is any education received after graduating from high school, and it differs significantly among the Indigenous peoples and other Canadians quantitatively and qualitatively. According to statistics, the Indigenous population is currently noticeably behind (more than 2.5 times) the total
Canadians in terms of university education. So, in 2020 $34 \%$ of Canadians aged 25-64 had a university degrees. However, the proportion of the Aboriginal population with university degrees in the same age group was $14 \%$. Post-secondary education for $41 \%$ of Aborigines develops as post-secondary - due to training in vocational schools and colleges [4].

The example of the Inuit is illustrative in this sense. According to the results of the 2012 study, $80 \%$ of Inuit aged 18 to 44 years had higher education (as a postsecondary education) - $48 \%$ graduated from one or twoyear college, $32 \%$ received certificates from vocational schools. Only $15 \%$ of the Inuit had a university education. For comparison, graduates of colleges and vocational schools from among non-Aborigines accounted for $50 \%$ (34\% received college diplomas, $16 \%$ received professional certificates), and $43 \%$ had university degrees [2], i.e. almost 3 times more than among Inuit.

One of the key tools for solving the problems of leveling education levels, improving school infrastructure, preserving or reviving native languages and culture is enhanced State funding of the Aboriginal education system. It allows one, firstly, at the expenses of additional resources (consultations of teachers, individual extra curriculum activities for students, etc.) to increase the academic performance of schoolchildren on and off reservations, as well as to prepare school graduates for the next stages of education - college and university. Secondly, this allows one to finance local projects for the preservation of the native language, the study of culture, traditions and ancestral experience through additional language courses, summer and winter thematic camps with training in traditional crafts, hunting and fishing, food culture, etc.; thirdly, to improve the material base of schools and cultural and educational centers in Aboriginal communities.

So, to support the education of Indigenous peoples, an unprecedented $\$$ was included in the budget of Canada in 20162.6 billion over 5 years, beyond existing funding, to improve elementary and secondary education on reserve resulting in a $37 \%$ increase in funding by 2021 [3].

Provincial and territorial Governments, along with federal authorities, also contribute to the support and funding of Indigenous education. For example, in the province of British Columbia in 2018, the Indigenous Learning Strategy program was created to finance the education of Indigenous students. According to this program, in the 2020-21 budget year, \$12.9 million was allocated to support the learning strategy, which was a \$1.6-million increase over the previous year [5]. However, its implementation has not yet led to a noticeable improvement in the academic performance of First Nations schoolchildren.

Canada has developed a strategy of collaboration of Federal authorities with Provincial and Territorial governments, Aboriginal communities and organizations to address current issues of education. For example, in January 2019, the Governments of Canada and British Columbia (BC) as well as the First Nations Education Steering Committee signed the new 5-year British 
Columbia Tripartite Education Agreement which responds to the education priorities and approaches of First Nations in British Columbia; includes significant new federal investments; will help ensure that all First Nations students receive a quality and culturallyappropriate education, whether they are attending one of the 131 First Nations schools on reserves, or a public or independent school off reserves [3].

The Government of Canada is implementing a number of educational programs to help the younger generation get post-secondary education and become more effectively involved in the country's economy. For example, the "Employment Strategy for First Nations and Inuit" [1] program supports initiatives that provide young people with information about professional knowledge and skills opportunities, as well as employment and career opportunities. Several federal and regional educational programs are aimed at helping Aboriginal youth to obtain higher education. Ultimately, they should help bridge the educational gap between Canada's Indigenous and non-Indigenous peoples. For example, the government of Canada increased funding to the Post-Secondary Student Support to support the University and College Entrance Preparation Program by $\$ 90$ million over two years beginning in 2017-2018. Budget 2019 invested $\$ 824$ million over 10 years to support Indigenous post-secondary education [3]. This funding will support post-secondary students and develop new post-secondary education strategies for Indians, Inuit and Metis.

The University and College Entrance Preparation Program (UCEPP) aims to help Indigenous students achieve the academic level necessary for admission to majors prioritized by Indigenous communities. This program provides irrevocable financial support to Indigenous students (First Nations) who are enrolled in accepted programs of preparation for admission to universities and colleges. The program covers student tuition fee and accommodation costs, textbooks and transportation costs.

The implementation of multicultural education in Canada for the Indigenous population is carried out within the framework of bilingual programs that pursue several goals. Firstly, to help children who do not speak the majority's language (English) to overcome psychological and academic barriers in learning and communication; secondly, to revive or maintain Indigenous languages that are on the verge of extinction. The school must fulfill its responsibilities to protect the Aboriginal language in such a way that the success of students in learning their native language helps in learning English and vice versa, success in English entails achievements in their native language.

However, teaching native languages, many of which are almost lost or spoken only by the older generation, remains one of the biggest problems in the school system of Indigenous peoples. If 40-50 years ago the main task of school education was to teach the Aboriginal peoples English based on the concept of bilingualism, now the emphasis has changed towards the study of native languages. In the report of the Ministry of Education of the Yukon Territory for 2020 The special importance of teaching schoolchildren their native language and culture was emphasized, as well as achievements and failures in this area, which are probably characteristic of the entire school system of Aboriginal peoples of Canada, were noted. Thus, in the 2019-20 academic year, only $38 \%$ of students attended Yukon Indigenous languages courses. Primary school students $(92.5 \%)$ were actively interested in these programs. However, only about $7 \%$ of high school students took such a course to study [6, p. 16]. Problems with the quality of teaching Aboriginal languages have not been solved either, because there are not enough teachers who speak them fluently, are qualified and certified.

Over the past five years (2016-2021), \$275 million has been allocated from the federal budget to support Indigenous languages and culture, which has allowed many provinces and territories to implement a number of educational programs in this direction [3].

According to the Indian Control of Indian Education Act, not only schools but also special language centers under the patronage of educational systems and libraries of provinces and territories should be engaged in the preservation and revival of Aboriginal languages and culture. For example, Yukon Native Language Centre is currently operating in Yukon. The Yukon Department of Education continues to provide the Council of Yukon First Nations with more than $\$ 1.2$ million annually to operate the Yukon Native Language Centre (YNLC). The YNLC supports community-based language initiatives, trains and certifies new language teachers, develops curriculum and resources, and preserves and documents Yukon First Nations languages [6].

Indigenous peoples' organizations and their local communities play a particularly important role in the implementation of programs for the study and preservation of Aboriginal cultures and traditions. It is this direction of public policy in the field of education that is the reaction of modern Canadian society to the previous destructive and aggressive policy of assimilation of Indigenous peoples. For example, Yukon schools have introduced programs to study the culture and practical experience of ancestral experience, as one of the ways to neutralize the negative background of the past. To do this, the Education Departments of almost all provinces and territories of Canada cooperate with Indigenous communities. So, Yukon Government has signed formal education agreements with some First Nations. This has led to the development of curriculum and programs in the traditional territories of those First Nations. For example, through the agreement with the Tr'ondëk Hwëch'in, three cultural camps have been accredited: First Hunt; First Fish; and Spring Camp [9]. Parents should check with their school to see how they are integrating Yukon First Nations ways of knowing, doing and being into class programming, which is quite consistent with one of the key principles of the Indian Control of Indian Education Act.

In British Columbia, the standard K-12 curriculum for students in grades 4-5 includes courses on Native American culture and traditional crafts. Indigenous knowledge and perspectives are integrated throughout all areas of learning and are evident in the curriculum's 
rationale statements, goals, big ideas, mandated learning standards, and elaborations. For example, the Textiles course studies sources of textile materials like leather, cedar, wool, cotton, felt, embroidery thread, yarn, grasses and reeds, pine needles, sinew, plastic, used items and fabrics (e.g., food wrappers, old clothing), personal factors that influence textile choices, including culture and self-expression, and the impact of those choices on individual and cultural identity. Identifying and using sources of inspiration and information may include experiences; traditional cultural knowledge and approaches, including those of First Peoples; places, including the land and its natural resources and analogous settings; and people, including users, experts, and thought leaders [11].

In addition to the problem of the quality and content of education for the Indigenous population, the issue of its material and infrastructural support is very acute. Many schools and school equipment do not meet the requirements, equipment for training sessions is outdated or missing, and school premises need to be repaired. The Government of Canada, together with Indigenous communities, is trying to solve these problems, primarily by financing the construction of schools and updating school infrastructure. For example, in November 2018, Bunibonibee Cree Nation, God's Lake First Nation, Wasagamack First Nation and Manto Sipi Cree Nation in Manitoba announced a \$248 million construction contract to build 4 new schools and renovate 1 school in their communities. In September 2018, Southeast Resource Development Council celebrated the grand opening of their expanded Southeast Collegiate campus in Winnipeg; Lake St. Martin First Nation in Manitoba celebrated the grand opening of their new kindergarten to grade 12 school. In June 2018, Paul First Nation in Alberta began construction of a new kindergarten to grade 9 school [3].

The COVID-19 epidemic has made additional adjustments to the learning process of the Indigenous peoples. Distance learning requires extensive use of IT and uninterrupted Internet access. Rural schools in the Northern and Arctic regions, as a rule, experience the greatest difficulties in this regard. During the lockdown, in Yukon schools, students and teachers use digital learning tools and platforms such as Microsoft Office 365, including tools such as Microsoft Teams and Word; $\mathrm{G}$ Suite for Education, including tools like Google Classrooms to host classroom; Moodle and MyNelson to provide online courses and access to e-textbooks; Zoom and YouTube to provide for online meetings and video lessons to students.

The transition to distance learning and the adaptation of schoolchildren and parents to it required new resources. Therefore, the Yukon Department of Education allocated additional funding to all students who studied in a standard K-12 program focused on the Indigenous population. The department's 2020 report says: "To help families offset some of the financial costs related to adapting to learning from home, we provided onetime direct funding support to families with children in $\mathrm{K}-12$ in May 2020. Families received $\$ 250$ per student, and applied for funds through Sport Yukon. In total, we allocated $\$ 1.28$ million through this initiative, directly supporting 4,595 K-12 students" [6, p. 5].

\section{Conclusion}

Thus a number of features are characteristic of Canada's modern policy of Indigenous peoples education: firstly, condemnation of the previous Government policy towards Aborigines at all levels - from federal to local authorities and society as a whole; secondly, monetary and moral compensation for the damage inflicted on Aborigines by the authorities in the previous period. The policy of the support for the Indigenous population in the education goes in several directions: equalization of the education levels of Indigenous peoples and other Canadians as a means of expanding the socio-economic opportunities of Aborigines; support for native languages and culture; improvement of the material and technical base of schools in Indigenous communities and educational infrastructure in general. The main tools in the implementation of these tasks are: financing of the Aboriginal education at the federal and regional levels; a collaboration of the authorities with public organizations and Indigenous communities. However, despite significant progress in the education system of the Indigenous peoples of Canada over the past decades, Government and public policy in this area needs further development and improvement.

\section{References}

1. Indigenous peoples. Canada.ca The official website of the Government of Canada. Retrieved from:

https://www.canada.ca/en/services/Indigenouspeoples.html

2. Inuit. Canada.ca The official website of the Government of Canada. Retrieved from: rnac.gc.ca/eng/1100100014187/1534785248701

3. Key priority: Quality education. Retrieved from: https://www.sac-

isc.gc.ca/eng/1523814808542/1523815053376?w bdisable $=$ true

4. Statistics Canada. Retrieved from:: https://www150.statcan.gc.ca/t1/tbl1/en/tv.action? pid=3710011701

5. Ferguson E. Graduation rates low for Indigenous students, despite \$13-million funding injection // Calgary Herald. Jan 17, 2021. Retrieved from: https:/calgaryherald.com/news/localnews/graduation-rates-low-for-Indigenousstudents-despite-13-million-funding-injection

6. Education annual report 2020| Government of Yukon. Retrieved from: yukon.ca>en/educationannual-report-2020

7. J. White, J. Peters, A Short History of Aboriginal Education in Canada, Aboriginal Policy Research Consortium International (APRCI). 23, 31, (2009).

8. Indian Control of Indian Education. Retrieved from: 
https://oneca.com/IndianControlofIndianEducati on.pdf

9. How First Nations perspectives are incorporated into schools. Retrieved from: https://yukon.ca/en/first-nations-perspectives

10. Government of Canada Newfoundland and Labrador residential schools healing and commemoration Retrieved from: https://www.rcaanccirnac.gc.ca/eng/1511531626107/153996200948 $\underline{9}$

11. Indigenous Knowledge and Perspectives: ADST K-12. Retrieved from: https://curriculum.gov.bc.ca/sites/curriculum.gov bc.ca/files/curriculum/Indigenous-knowledgeand-perspectives/adst-k-12-Indigenousknowledge-and-perspectives.pdf 